\title{
MASS BALANCE OF ICE STREAM B, WEST ANTARCTICA
}

\author{
by
}

I.M. Whillans

(The Ohio State University, Byrd Polar Research Center, and Department of Geology and Mineralogy, 125 South Oval Mall, Columbus, OH 43210, U.S.A.)

and

R.A. Bindschadler

(Oceans and Ice Branch, Code 671, NASA / Goddard Space Flight Center, Greenbelt, MD 20771, U.S.A.)

\section{ABSTRACT}

The mass balance of the drainage area of Ice Stream B, West Antarctica, is calculated from new measurements of both discharge and accumulation rate. The discharge is computed for a transverse section near the lower end of the ice stream. Velocities have been obtained for 787 sites, using repeated photogrammetry, with ground control by Transit (doppler) satellite tracking. Thicknesses have been obtained by radio echo-sounding. The uncertainties in the discharge calculations are only about 3\%. Net accumulation is derived from profiles of gross beta activity and from identification of the $1954-55$ and $1964-65$ nuclear-bomb strata. The major uncertainties are associated with the identification of the catchment area and with the accumulation rate. Accumulation rate varies locally, probably due to the interaction of katabatic wind with local slope, and many spot measurements are needed to obtain a good regional mean. The integrated input is $21.4 \pm 5.2 \mathrm{~km}^{3} \mathrm{a}^{-1}$, and the output is $30.0 \pm 1.0 \mathrm{~km}^{3} \mathrm{a}^{-1}$. The deficit is thus $8.6 \pm 6.2 \mathrm{~km}^{3} \mathrm{a}^{-1}$, which corresponds to a mean thinning rate of $0.06 \mathrm{~m} \mathrm{a}^{-1} \pm 0.04 \mathrm{~m} \mathrm{a}^{-1}$. The difference from earlier estimates is mainly due to the refined catchment area and accumulation. The imbalance is significant but smaller than previously calculated: for balance the accumulation rate or catchment area would need to be about $39 \%$ larger or the ice stream velocity would need to be $28 \%$ slower.

\section{INTRODUCTION}

There is discussion on the stability of the West Antarctic ice sheet. It may be inherently unstable and in such delicate balance that a small change in climate or sea-level would cause dramatic changes. Early evidence (e.g. Whillans 1977, Rose 1979, Jezek 1984) indicated that it was already changing, even before anthropogenic effects could have become important. Precise measurements of the current mass balance are therefore needed and the causes for any imbalance need to be addressed.

The mass balance is measured by comparing input with output. This can be done at various scales, from local, as for the Byrd Station Strain Network (Whillans 1977), to very large, as for all of Antarctica (e.g. Bull 1971). Here the mass balance of a single basin, the drainage basin of Ice Stream B (Fig. 1), is assessed. For this region the input is by snow accumulation and the output is by flow measured near the narrowest point in Ice Stream B.

Prior work indicates a negative balance for this basin. Shabtaie and Bentley (1987) reported -11.5 to $-20.0 \mathrm{~km}^{3} \mathrm{a}^{-1}$; the range derives mainly from an ambiguity in how the existing maps of the region of snow accumulation should be interpreted. Shabtaie and Bentley computed the discharge from four velocities at the ice-stream mouth and extrapolated across the ice stream according to an

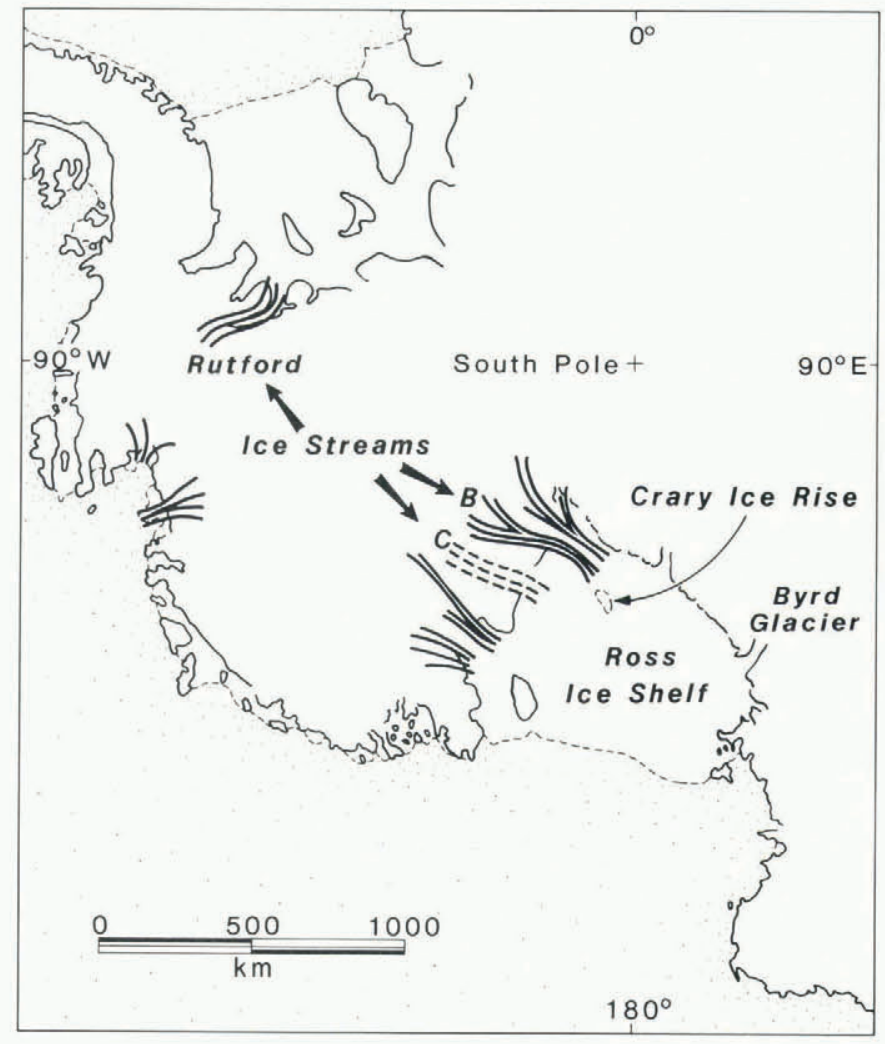

Fig. 1. Location of Ice Stream B.

unspecified criterion. More recently, Whillans and others (1987) made a similar calculation, using a catchment area obtained from a newer map of elevations (Shabtaie and others 1987) and using velocities measured and extrapolated by calculation across the ice stream. The result is similar: $-16.5 \pm 6.1 \mathrm{~km}^{3} \mathrm{a}^{-1}$ of ice of density $910 \mathrm{~kg} \mathrm{~m}^{-3}$. The principle of these works is the same as used here, but both earlier calculations suffer from a paucity of data on the transverse-velocity profile and on accumulation rates.

Most previous estimates are based mainly on the accumulation-rate data summarized by Bull (1971). There are large regions of the catchment for which no data exist, and Bull expresses considerable reservation about the accuracies of the values. They are obtained from the interpretation (often by inexperienced observers) of structural variations in shallow firn, and typically apply to accumulation over only a 2 year interval. 
The present contribution is a recalculation of the mass balance of Ice Stream B and its catchment area, with the inclusion of new data both on output by flow and on snow input.

\section{OUTPUT}

The outflow is obtained from 787 measurements of surface velocity on a transect across the ice stream, corrected for shear at depth, and integrated over a crosssection of the ice stream.

The surface velocities come from repeated photogrammetry. Ground control is from the tracking of Transit (or doppler) satellites (Whillans and others 1987). Black plastic targets were left suspended between bamboo poles at the satellite-tracking stations in order to mark their locations in the photographs. The photography was obtained with a Wild RC8 camera in an LC- 130 Hercules aircraft at $6100 \mathrm{~m}$ altitude. The procedure was carried out in January 1985 and January 1986. Here results for the "40" block are used. That block crosses Ice Stream B just down-glacier of its narrowest point. This transect is $180 \mathrm{~km}$ up-glacier of the grounding line, and $90 \mathrm{~km}$ up-glacier of the transect used by most authors hitherto to estimate output flux.

In the laboratory the photographs are measured on an analytic plotter (Wild model BC-1). They are first linked, using sastrugi and other features to form stereo models for each pair of photographs. A least-squares adjustment of the entire linked block of about 40 photographs, together with the ground control, provides the position, orientation, and scale of each stereo model. The photographs are then remounted and the position of crevasses and drift mounds that appear on both sets of photographs are measured.

The procedure differs from that of Brecher (1986) for Byrd Glacier, in that the control is only by satellite tracking and in the two-step use of an analytic plotter. Brecher used the same points to tie the photographs and to measure velocity. This was practicable for the completely crevassed Byrd Glacier, but there are stretches of Ice Stream B without visible crevasses, and sastrugi must be used. In addition, an analytic plotter makes it easy to remount the photographs and obtain more velocities. Where there are sufficient drift mounds and crevasses, velocity vectors have been obtained for each $1 \mathrm{~km}^{2}$ (compared with one velocity vector per $6 \mathrm{~km}^{2}$ for Byrd Glacier).

Errors in the velocities have not been fully evaluated. They are largely associated with the ability to identify features in the January 1986 photographs, which were taken through ground fog. Ice features on these photographs are indistinct and repeated selection of the same feature indicates errors of up to $5 \mathrm{~m} \mathrm{a}^{-1}$ for the velocity of the features most difficult to identify. There are also errors of $3 \mathrm{~m} \mathrm{a}^{-1}$ in the control (Whillans and others 1987) and a further $2 \sigma$ error of $4 \mathrm{~m} \mathrm{a}^{-1}$ in the photogrammetric adjustment. In combination, these factors result in error limits of $\pm 12 \mathrm{~m} \mathrm{a}^{-1}$ for the velocities.

The component of velocity perpendicular to the dog-legged lines joining stations 41,42 , and 43 are gridded, using a Krigging procedure. This is, in essence, an interpolation scheme for obtaining values at regular intervals. The resulting component across that line is shown in Figure 2. The dashed part indicates where there are no velocity data.

This measured velocity profile is different from that predicted by either Whillans and others (1987) or by Shabtaie and Bentley (1987) and Shabtaie and others (1988, this volume) (although a minor difference is that the latter authors work with velocity magnitudes rather than velocity components). It is neither block-like, nor does side shearing extend across the ice stream in a simple manner. A fuller analysis of these data will be presented in a later contribution.

The depth variation in velocity is very small and most of the motion is due to basal sliding. The surface slope is about 0.002 and so the driving stress for the full thickness of $1000 \mathrm{~m}$ is $18 \mathrm{kPa}$. Ignoring longitudinal stress gradients, the shear stress on horizontal planes is taken to vary linearly from zero at the surface to $18 \mathrm{kPa}$ at the bed. The measured surface strain-rates indicate that the effective strain-rate at the surface is $0.13 \mathrm{a}^{-1}$ or somewhat less. This

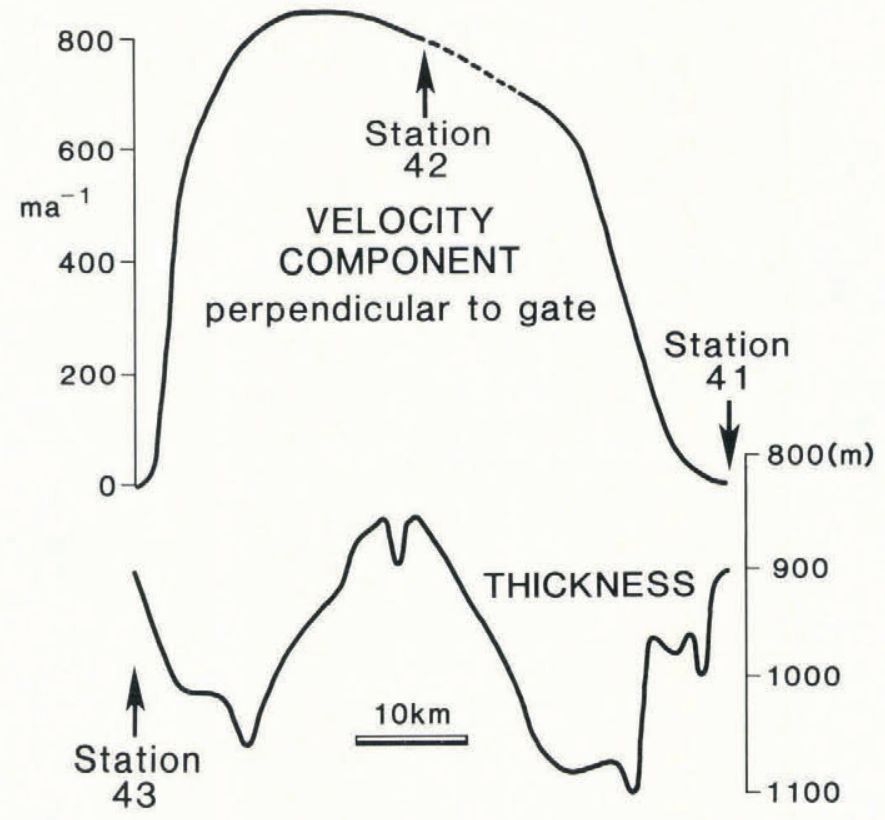

Fig. 2. Top: velocity from repeat photogrammetry; the dashed part is interpolated because there are no crevasses from which to trace velocity. Bottom: radio-echo thickness profile (personal communication from S. Shabtaie, 1987). Station 41 is at the south-eastern edge of the ice stream, station 43 is at the north-western edge, and station 42 is almost on the line that joins stations 41 and 43 .

corresponds to an effective shear stress of $355 \mathrm{kPa}$ (using an ice temperature of $-27^{\circ} \mathrm{C}$ and flow-law parameters from Hooke (1981)), which dominates the vertical shear stress. Integration of the flow law with this value of effective shear stress for all depths and a constant temperature yields a deformation component to the surface velocity of only $10 \mathrm{~m} \mathrm{a}^{-1}$. The depth-averaged value of this component is only $2 \mathrm{~m} \mathrm{a}^{-1}$. Both the effective strain-rate and the temperature are expected to be greater at depth than at the surface. However, even if the ice is taken to be temperate throughout, which it clearly is not, the integration yields a depth-averaged velocity still only $6 \mathrm{~m} \mathrm{a}^{-1}$ less than at the surface. This upper limit to the adjustment is within the measurement error of the surface velocity and is ignored. The contribution of basal sliding is thus so important that surface velocities may be used to represent mean velocities.

Thicknesses (lower panel in Fig. 2) were provided by S. Shabtaie from a radio-echo-sounding flight along the same transect. As established by Shabtaie and Bentley (1987), these are accurate to $\pm 18 \mathrm{~m}$ (twice the standard deviation).

The discharge includes the product of the velocity and thickness. Integrated across the gate, this discharge (of ice of density $920 \mathrm{~kg} \mathrm{~m}^{-3}$ ) is $30.0 \pm 1.0 \mathrm{~km}^{3} \mathrm{a}^{-1}$.

\section{INPUT}

The catchment area is determined by drawing flow lines perpendicularly to elevation contours on the new map of Shabtaie and others (1987). The maximum and minimum possible boundaries of the drainage basin were drawn by different glaciologists and these are shown in Figure 3. The average area is $147000 \mathrm{~km}^{2}$ and the maximum and minimum areas differ by $12 \%$ from the average.

Accumulation rates are obtained from gross betaactivity profiles of hand-augered cores from the sites indicated by underlined values in Figure 3 . Samplepreparation procedure follows a method similar to that of Delmas and Pourchet (1978), in which the radioactive isotopes (mainly ${ }^{137} \mathrm{Cs}$ and ${ }^{90} \mathrm{Sr}$ ) are concentrated on ion-exchange filters (in our case, only cationic filters). The radioactivity of the filters is then measured by using a 


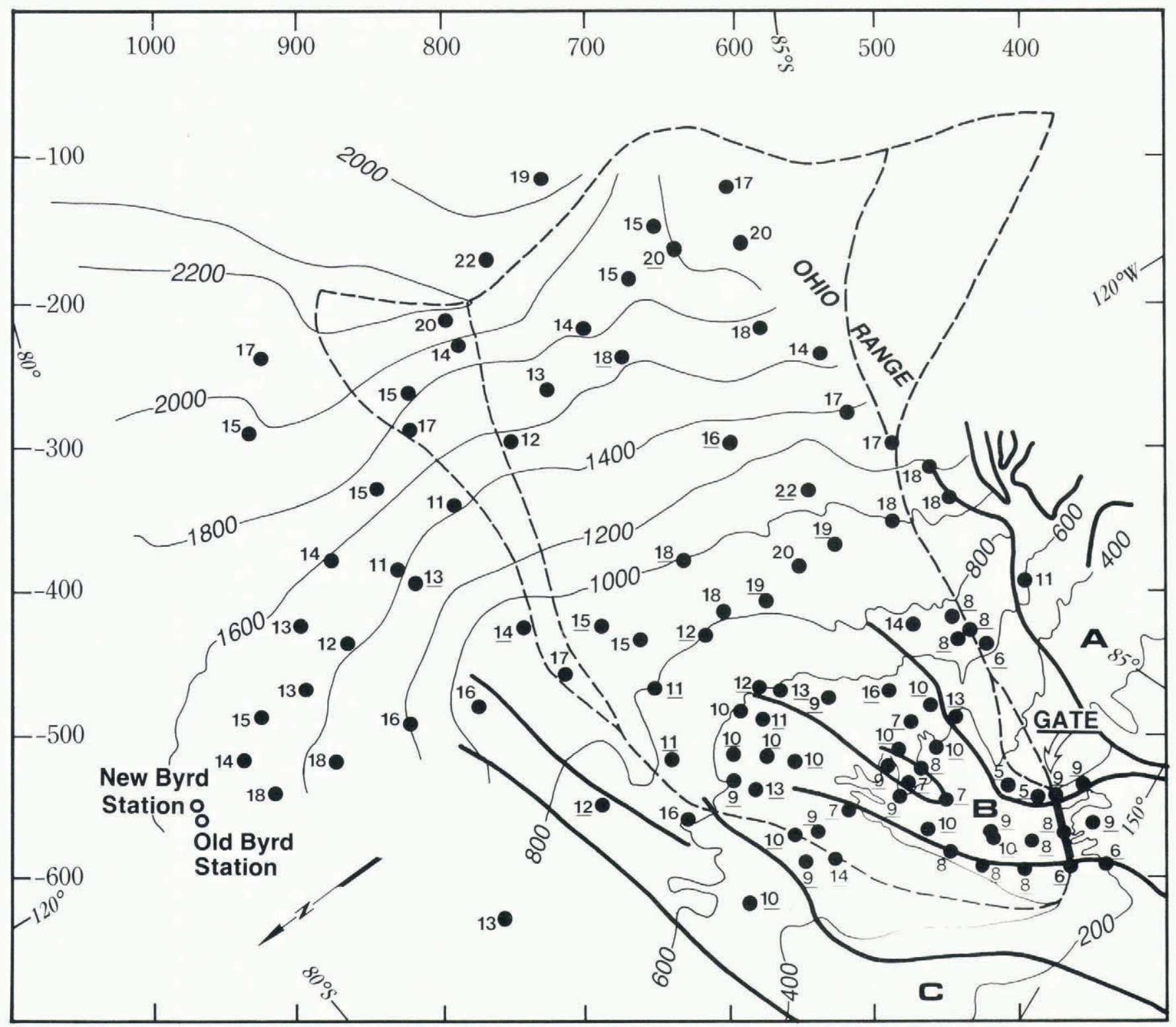

Fig. 3. Accumulation rates in centimeters of ice per year. Underlined values are new and derive from measurements of gross beta activity. Other values are traverse-era structural interpretations from Bull (1971). Output-velocity data are those from the gate at the lower end of Ice Stream B. Dashed lines show possible limits of the catchment. The base map is taken from Shabtaie and others (1987) and the coordinate system follows Whillans and others (1987).

gas-flow proportional counter with a cosmic guard and a lead-brick enclosure. Figure 4 shows representative profiles on which estimated nuclear-bomb fall-out levels are indicated.

Sample preparation and counting efficiency is about $30 \%$. So, for comparison with the results of (for example) Pourchet and Pinglot (1979) or Clausen and others (1979), the values here should be multiplied by about 3 and allowance should be made for radioactive decay between the time of those measurements and our measurements (made in 1986 and 1987).

Allowing for this, the activity reported here for Marie Byrd Land and for Ross Ice Shelf (Clausen and others 1979) is about one-third that for South Pole Station (Pourchet and Pinglot 1979), which has about the same snow-accumulation rate. To explain such results, Pourchet and others (1983) argue for the relative importance of dry deposition versus scavenging of radioactive isotopes by snow, but that explanation does not work well here. The contrast in activity may rather be due to the difference in elevation between the two regions. The fall-out arrives in Antarctica in the stratosphere, and over central East Antarctica there is a sinking motion that brings fall-out to the surface. As a result, stratospherically derived air is proportionately more important on the high East Antarctic plateau. In West
Antarctica, air advected through the troposphere is more important. A larger stratospheric component at the South Pole may account for its higher activity.

The depths of the samples are calculated from the drilling records, with allowance for core loss according to Whillans and Bolzan (in press). In only four cases does the uncertainty in depth lead to uncertainty in accumulation rate in excess of $0.01 \mathrm{~m} \mathrm{a}^{-1}$, but these sites are on the ice stream and are not critical here.

Critical to accumulation rate is the density profile, to which a large part of the estimated error is due. The accumulation rate is obtained by summing masses, $M$, divided by the square of the diameter, $\phi$, according to

$$
\text { accumulation rate }=\frac{4}{\pi}\left(\Sigma \frac{M}{\phi^{2}}\right) / \text { (age of stratum) }
$$

with allowance for the mass of unrecovered sections. The sum is taken from the surface to the depth of the dated stratum. The diameter, $\phi$, is most reliably measured at core recovery. It may be affected subsequently by shrinkage due to sintering during shipment and storage. It is very variable, especially at shallow depths, where the firn is friable. The standard deviation on the mean diameter is $2 \%$ (White, unpublished). Masses measured in the field may be less reliable than those obtained in the laboratory because of the 


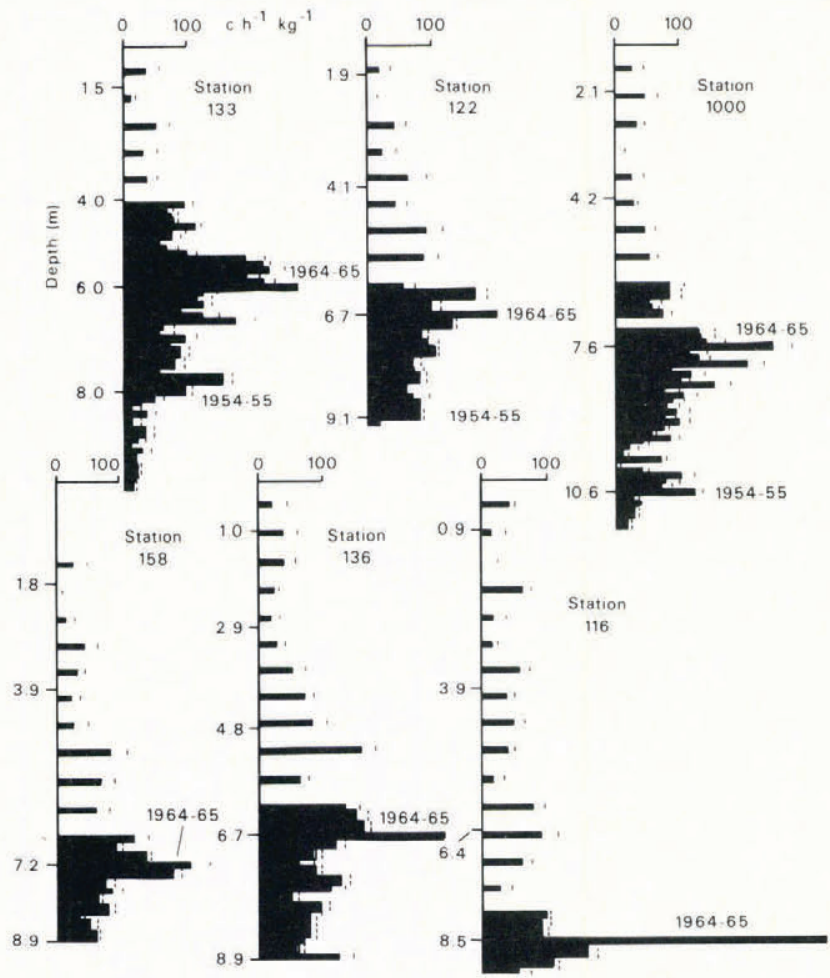

Fig. 4. Gross beta profiles for six sites in the catchment area. Vertical axes are linear in the sample number but selected depths are indicated. Not all samples have been measured. Bars indicate measured counts, and short vertical lines are at an additional one standard deviation according to counting statistics.

effects of wind on the measuring balance, but a comparison indicates little difference from the laboratory masses, and this work uses field diameters and masses. Errors due to density determination are estimated to be less than $\pm 6 \%$.

Core loss above the bomb strata is typically $0.1-0.3 \mathrm{~m}$, and the density of the missing pieces is assigned the mean of the recovered segments above and below them. This probably biases the calculated accumulation rate upward by a small amount because it is low-density firn that tends not to be recovered. The bias is estimated to be only about $0.5 \%$ and the results have not been corrected to allow for it.

The stratigraphic fall-out horizons that are used are the broad peak during the 1964-65 austral summer and the increase during the 1954-55 austral summer (Clausen and others 1979, Pourchet and Pinglot 1979). These features are readily identifiable in nearly all profiles. Some cores are too short to include the 1954-55 level. One site (no. 137 at $-290,550 \mathrm{~km}$ in Fig. 3) unaccountably lacks any bomb level and is omitted. Another site (no. 144) has very confused records of core recovery and is also omitted. Where both stratigraphic levels are identified, they provide (with only one exception) the same accumulation rate, within the error limits for sastrugi and inter-annual variability discussed below.

Figure 3 shows the results, together with the traverse-era values compiled and interpreted by Bull (1971) The new data generally confirm the traverse-era field interpretations of annual strata and so Bull was overly pessimistic about the reliability of his compilation. In the present work both the old and the new data are used.

The variations in accumulation rate in Figure 3 are due to a combination of geographic pattern, sastrugi roughness, and secular variation. Secular variation is important because the traverse-era results pertain to only about 2 years in the $1950 \mathrm{~s}$ and $1960 \mathrm{~s}$, and the new results pertain to the longer periods $1965-86$ and 1955-86. Sastrugi make each depositional surface irregular, so that there is an uncertainty in using spot measurements to represent areal means.
Sastrugi roughness and inter-annual variability have been determined nearby, at Byrd Station. Sastrugi roughness, $\sigma_{\mathrm{S}}$, is $20 \mathrm{~kg} \mathrm{~m}^{-2}$ or $0.02 \mathrm{~m}$ of ice (one standard deviation), and inter-annual variability, $\sigma_{\mathrm{a}}$, is coincidentally the same, $0.02 \mathrm{~m}$ of ice (Whillans 1978). Both the upper and the lower strata are affected by sastrugi, and every year within the interval may show inter-annual variation; so together these account for a variability of $\left(2 \sigma_{s}^{2}+t \sigma_{a}^{2}\right)^{\frac{1}{2}} / t$ for a time span of $t$ years. Sastrugi roughness for strata inside the interval is of no consequence. The traverse-era determinations generally cover 2 years (Vickers 1966) and that leads to a net standard error of $0.02 \mathrm{~m} \mathrm{a}^{-1}$ of ice. The new data cover 21 years or more and that leads to $0.005 \mathrm{~m} \mathrm{a}^{-1}$, or (taking error limits at twice the standard deviation) sastrugi and inter-annual variability account for about $\pm 0.01 \mathrm{~m} \mathrm{a}^{-1}$ for the new data.

There is a second kind of local variability - that associated with surface slope. Along the Byrd Station Strain Network the accumulation rate varies by $30 \mathrm{~kg} \mathrm{~m}^{-2} \mathrm{a}^{-1}$ or $0.03 \mathrm{~m} \mathrm{a}^{-1}$ at a scale of $5 \mathrm{~km}$, in close association with surface slope. Gow and Rowland (1965) consider these to be giant snow dunes, but the slope variations are due to ice flow, being steep where there is a basal obstruction (Whillans 1987). The accumulation rate is least where the slope is greatest, and a simple calculation shows that the speed of inversion (or katabatic) winds responds to such changes in local slope (Whillans 1975). Snow deposition is more likely where the slope is least and the winds slowest. Thus, unlike the effects of sastrugi (which become less important when accumulation is measured over long time intervals), this slope-related variation adds an error-limit uncertainty of $\pm 15 \mathrm{~kg} \mathrm{~m}^{-2} \mathrm{a}^{-1}$ or $\pm 0.016 \mathrm{~m} \mathrm{a}^{-1}$ to all spot measurements, compared to the regional mean for regions where there are local variations in slope. This is expected to apply wherever inland ice flows over a rough bed and katabatic winds are important: that is, to most of the catchment area.

These variabilities from along the Byrd Station Strain Network are similar to those of Shabtaie and Bentley (1987), who followed the methods of Giovinetto (1964). Their $\alpha$ error is attributed to problems in identifying buried strata. This is an unimportant problem with the new data reported here. However, the $\alpha$ error is numerically equivalent to our sastrugi noise, which Giovinetto did not specifically recognize. Their interpolation error, $\beta_{1}$, seems to be equivalent to our local surface-slope effect, and the estimates are about equal. Their $\gamma$ error describes interannual variability, $\sigma_{2}-$ and perhaps some sastrugi effects (personal communication from C.R. Bentley, 1987) - and, although their estimate is about twice ours, it is still small compared to effects of local slope. By either account, effects of local sastrugi and slope, amounting to about $\pm 1.5 \mathrm{~cm}$ of ice $\mathrm{a}^{-1}$, explain most of the scatter in Figure 3.

The variability due to the effects of local slope, to sastrugi, and secular variation thus accounts for much of the variation in both the new data and the traverse-era results. Outside this small-scale scatter, there is a broad geographic pattern in Figure 3. Accumulation rates are larger to the south-east (toward the top of the figure)

This geographic pattern has similarities to that inferred by Giovinetto and Bentley (1985) according to considerations of such factors as atmospheric-condensation levels, distance from the ocean, and direction of lower-tropospheric flow. The authors do not explain exactly how these considerations lead to the predicted values. The large values near the Transantarctic Mountains extend on to Ross Ice Shelf (Clausen and others 1979) and the pattern may be due to lifting of air over a wedge of cold air trapped in front of the range, as has frequently been observed (Schwerdtfeger 1984, section 3.3.2). That explanation may apply on Ross Ice Shelf, but the accumulation-rate gradients in Marie Byrd Land are not as steep and not in close proximity to the mountain barrier.

A related possibility for the pattern is that it may be associated with contrasts in surface-wind speed. Parish and Bromwich $(1986,1987)$ simulated surface-air flow by inversion or katabatic winds. They found that there is a concentration of stream lines into the region near Ice Stream B that is consistent with direct surface observations made by field parties of our project. Regions where there 
is faster wind may have smaller accumulation rates. Higher wind speeds are expected where the surface-elevation contours are broadly concave down-slope. The main convergence of stream lines is, however, displaced somewhat to the south of the center of the region of low accumulation rate.

Some glaciers have a low net accumulation rate in their lower reaches as a result of the effects of föhn or chinook winds. Such major evaporative sublimation is discounted for West Antarctica because the region of low net accumulation extends far out on to Ross Ice Shelf (Clausen and others 1979), where surface slope and katabatic flow are near zero. In addition, sub-surface temperature varies little along flow, suggesting that adiabatic heating plays a minor role.

The simplest explanation for the broad pattern is that it is mainly orographic. Inspection of Figure 3 shows that, on average, accumulation rate correlates with mean surface slope, suggesting that the accumulation is derived from lifting of moist air travelling up-slope, and that a roughly constant amount of accumulation is generated for each lifting increment.

The data on accumulation rate describe a fairly simple geographic pattern, although more measurements are needed to refine the pattern and to test whether the local variability is as large as we argue here. The areally weighted mean accumulation rate over the catchment is $0.143 \pm 0.014 \mathrm{~m} \mathrm{a}^{-1}$ of ice. The error limits are due almost entirely to uncertainty in the regional mean accumulation rate above $1000 \mathrm{~m}$ elevation. That is assigned an uncertainty of $\pm 0.020 \mathrm{~m} \mathrm{a}^{-1}$ of ice. Below that elevation there are 65 determinations and the error on the mean is only about $\pm 0.010 \mathrm{~m} \mathrm{a}^{-1}$, and is due to inter-annual variability.

In addition to snow accumulation, the mass input is affected by basal melting or freezing. This, however, is very small. It is due to the balance of geothermal heat and frictional heat due to ice flow, less the heat conducted upward into the ice sheet. Any net water so produced escapes from under the ice sheet and is not part of the discharge measured by ice flow. At Byrd Station the upward conduction is $0.075 \mathrm{~W} \mathrm{~m}^{-2}$ (Gow and others 1968). Typical geothermal heat flow is $0.057 \mathrm{~W} \mathrm{~m}^{-2}$ for continents and $0.060 \mathrm{~W} \mathrm{~m}^{-2}$ for old ocean floor (Turcotte and Schubert 1982, pp. 137, 165). Marie Byrd Land has characteristics of both old ocean floor and continents, and we use the round number $0.060 \mathrm{~W} \mathrm{~m}^{-2}$ (which is also the middle value used by Lingle and Brown (1987)). Frictional heating also contributes to melting and it is generated by sliding and deformation near the bed. At Byrd Station the velocity near the bed is not well known (Paterson 1983) but is between 0 and $8 \mathrm{~m} \mathrm{a}^{-1}$ (Whillans 1979). The mean driving stress for that region is about $50 \mathrm{kPa}$. The frictional heat available is approximately the driving stress times the velocity: that is, $0.02 \mathrm{~W} \mathrm{~m}^{-2}$. There can thus be net heat gain of $0.005 \mathrm{~W} \mathrm{~m}^{-2}$, which melts ice at the negligible rate of $0.0005 \mathrm{~m} \mathrm{a}^{-1}$. This calculation is very rough and Byrd Station may not be typical. The thickness at Byrd Station is, however, in the middle of the range for the region. Typical velocities may be faster than at Byrd Station but frictional heat cannot, in any case, be very important. Taking a somewhat different approach, one may note that there is $4-5 \mathrm{~m}$ of refrozen ice at the base at Byrd Station (Gow and Williamson 1976, p. 1675), which indicates net basal freezing up-glacier. The response time for the reaction of the region near Byrd Station to climatic change is 15000 years (Whillans 1981). The assumption that the net freezing has been in effect for at least that long yields a net freezing rate of less than $0.001 \mathrm{~m} \mathrm{a}^{-1}$. We apply wider error limits than the range produced by these calculations and take the basal melting to be $0 \pm 0.005 \mathrm{~m} \mathrm{a}^{-1}$, which is negligible.

The net input is obtained by multiplying the mean surface accumulation for each $200 \mathrm{~m}$ elevation interval times the area of that interval. The $\pm 0.005 \mathrm{~m} \mathrm{a}^{-1}$ uncertainty in basal melting is also included. This yields an input rate of $21.4 \pm 5.2 \mathrm{~km}^{3} \mathrm{a}^{-1}$, of which about half of the uncertainty originates in the accumulation rate and about half in the area.

\section{RESULTS}

The difference between input and output is $8.6 \pm 6.2$ $\mathrm{km}^{3} \mathrm{a}^{-1}$, which is equivalent to an average thinning rate of $0.06 \pm 0.04 \mathrm{~m} \mathrm{a}^{-1}$. The errors are considered to be error limits, and not the statistically based standard deviations of, for example, Shabtaie and others (1988, this volume). The imbalance is significant.

The major uncertainties are associated with the accuracy of the boundaries of the catchment area and with the mean accumulation rate. Both can be improved with further work. The catchment area can be delineated better by using measurements of velocity vectors near the limits of the catchment area, and more cores for gross beta activity would refine the accumulation rate. The ultimate practical limit to the accuracy of such a determination is likely to be the local variability in accumulation rate.

The imbalance has long-term significance. The accumulation rates have been nearly constant for 1700 years (Gow 1968).

COMPARISON WITH EARLIER ESTIMATES OF INPUT RATE

The input rate obtained here differs from earlier results mainly because of the use of the new elevation map of Shabtaie and others (1987) and partly because we have more data on accumulation rate. The results are compared in Table I. The table omits the result of Whillans and others (1987), however, because there is a calculation error in that work.

Hughes (1973), Rose (1979), Lingle and Brown (1987), and version 1 in Shabtaie and Bentley (1987) use progressively up-dated results of the NSF-SPRI-TUD radioecho-sounding program. The more recent versions lead to a problem in defining the boundaries between ice streams B and $C$. The ice flow is expected to be approximately perpendicular to elevation contours. In addition, the flow of ice streams is supposed to be approximately parallel to linear crevasse margins. On the recent NSF-SPRI-TUD maps, the crevasse margins of the upper part of Ice Stream $\mathrm{C}$ are diagonal to the elevation contours. It is questionable whether the flow should be taken perpendicularly to elevation contours (Lingle and Brown 1987), to produce a catchment area of $203000 \mathrm{~km}^{2}$, or whether it should be taken parallel to the crevasse lines (Rose 1979), to produce $163000 \mathrm{~km}^{2}$. Shabtaie and Bentley (1987) do it both ways and obtain 217000 ("new model") and 159000 (version 1) $\mathrm{km}^{2}$ respectively. Shabtaie and others (1988, this volume) obtain similar numbers to those for "version 1" in Shabtaie and Bentley (1987).

The new map of Shabtaie and others (1987) mostly resolves this problem. It is based on ground control by Transit satellite tracking and interconnecting radar flights. These more accurate elevation contours, where supported by flight-line data, are more nearly perpendicular to the crevasse lines. The two methods are now consistent and the smaller catchment area obtained here is in line with them.

Another reason for the variation in calculations is that the position of the output gate differs. Early calculations are for the DNB camp (long. $154^{\circ} \mathrm{W}$ ), where the grounding line was believed to be located. Our value of the catchment area for that site is $156000 \pm 17000 \mathrm{~km}^{2}$.

There is also some variation in accumulation rate among authors. Hughes (1973) and Rose (1979) use Bull's (1971) compilation but obtain different means, of 17 and 11 $\mathrm{cm}$ of ice per year. Part of the difference arises because Hughes's catchment is farther south, where accumulation rates are larger. Shabtaie and Bentley (1987) add data from Clausen and others (1979), but omit data that Bull found questionable. Lingle and Brown (1987) use all these data, as well as other recent sources, and find a mean of $14.6 \mathrm{~cm}$ of ice per year, much as we do, and we include further new data. 
TABLE I. ESTIMATES OF FLUX OF ICE STREAM B

\begin{tabular}{|c|c|c|c|c|c|}
\hline Author & $\begin{array}{c}\text { Area } \\
\left(1000 \mathrm{~km}^{2}\right)\end{array}$ & $\begin{array}{l}\text { Accumulation } \\
\text { rate } \\
\left(\mathrm{cm} \text { of ice } \mathrm{a}^{-1}\right)\end{array}$ & $\begin{array}{l}\text { Input } \\
\text { flux } \\
\left(\mathrm{km}^{3} \mathrm{a}^{-1}\right)\end{array}$ & $\begin{array}{l}\text { Discharge } \\
\left(\mathrm{km}^{3} \mathrm{a}^{-1}\right)\end{array}$ & $\begin{array}{l}\text { Output } \\
\text { gate } \\
\text { (longitude) }\end{array}$ \\
\hline Hughes (1973) & 193.6 & 16.5 & 32.6 & & $154^{\circ} \mathrm{W}$ \\
\hline Rose (1979) & 163 & 11 & 18 & & $154^{\circ} \mathrm{W}$ \\
\hline $\begin{array}{l}\text { Lingle and Brown } \\
\text { (1987) }\end{array}$ & 203 & 14.6 & 29.6 & & $154^{\circ} \mathrm{W}$ \\
\hline $\begin{array}{l}\text { Shabtaie and } \\
\text { Bentley (1987) } \\
\text { version 1 } \\
\text { "new model" }\end{array}$ & $\begin{array}{l}159 \pm 18^{*} \\
217 \pm 28^{*}\end{array}$ & $\begin{array}{l}10.9 \pm 3.8^{*} \\
11.9 \pm 4.2^{*}\end{array}$ & $\begin{array}{l}17.3 \pm 6.4^{*} \\
25.8 \pm 9.8^{*}\end{array}$ & $\begin{array}{l}37.3 \pm 4.6^{*} \\
37.3 \pm 4.6^{*}\end{array}$ & $\begin{array}{l}162^{\circ} \mathrm{W} \\
162^{\circ} \mathrm{W}\end{array}$ \\
\hline $\begin{array}{l}\text { Shabtaie and } \\
\text { others (1988, } \\
\text { this volume) }\end{array}$ & $163 \pm 20^{*}$ & $10.9 \pm 3.8^{*}$ & $17.8 \pm 6.4^{*}$ & $\begin{array}{l}37.3 \pm 4.6^{*} \\
31.3 \pm 2.7^{*+}\end{array}$ & $\begin{array}{l}162^{\circ} \mathrm{W} \\
147^{\circ} \mathrm{W}\end{array}$ \\
\hline This paper & $147 \pm 17$ & 14.3 & $21.4 \pm 5.2$ & $30.0 \pm 1.0$ & $\begin{array}{l}\text { "40" } \\
\text { block, } \\
147^{\circ} \mathrm{W}\end{array}$ \\
\hline
\end{tabular}

\footnotetext{
*using \pm limits as twice the standard error

+ average of their gates G3 and G4
}

\section{DISCUSSION}

The calculation indicates an imbalance for the entire region, but more rapid thinning or thickening could exist in smaller parts of the region. In view of the great variety of flow regimes in this region, it seems unlikely that the thinning is spatially uniform. Candidates for local thinning include the inter-stream ridges, the lateral margins of the ice streams, and the heads of the ice stream, and there are other possibilities.

Perhaps the most attractive process for thinning is the growth of ice stream at the expense of inland ice. The surfaces of ice streams are generally at lower elevations than those of neighboring inland ice, and so conversion would entail a drop in elevation. This conversion could be by lateral growth of ice stream into the inter-stream ridges, or by lengthwise growth of the ice stream into the main inland ice.

Support for the possibility of ice-stream lengthening is afforded by the complexity of flow at the head of Ice Stream B. In that region the velocity varies in unusual ways; some velocities are even reversed or transverse to the main flow (stations 72 and 27 in Whillans and others (1987)). Moreover, the velocities are not simply linked to zones of crevasses detected by radar (e.g. station 55 in fig. 2 in Whillans and others (1987)), and calculations of local mass balance which use the velocity data indicate local thinning rates that reach $16 \mathrm{~m} \mathrm{a}^{-1}$. That can account for the entire imbalance obtained here.

Shabtaie and others (1988, this volume) pursue this idea of local thinning by considering six segments of the ice stream. They assume that the ice stream flows in a block-like fashion between boundaries inferred from crevassing detected by radar. (The exceptions discussed above are probably insignificant in their calculation, and the assumption of block-like flow is not critical if the shape of the velocity profile is nearly constant). Allowance is made for flow of ice across the crevasse zones, and they conclude that the ice stream is thinning by $0.8 \mathrm{~m} \mathrm{a}^{-1}$ near its head but that it is thickening down-glacier.

Secular thinning at the heads of the ice streams is a strong possibility but has not been proved, and a more conservative interpretation is that the transition from inland ice to ice-stream flow is spatially complex - more complex than the spacing of available velocity measurements can resolve. The "wrong-way" velocities and apparent thinning

calculated from the velocities could be evidence of non-steady flow or of short-term irregularities in which rafts of inland ice are being detached, jostled, and incorporated into the ice stream. Even down-glacier, at the output gate, there are important velocity gradients across the ice stream (Fig. 2). It is expected that these gradients are more complex up-glacier, where the ice stream forms and where there are multiple shear zones.

Another possibility for local thinning is the lateral growth of the ice stream into the inter-stream ridge. This requires a secular elevation decrease at the site of conversion, which may be happening at the boundary of Ice Stream B with the ridge A/B. Near the output gate there are crevasses on the ridge and, on the map of Shabtaie and others (1987), a curious gully in ridge A/B. These are difficult to account for by steady flow, and major changes may be in progress there.

Overall collapse of the inter-stream ridges can be discounted. The ice flow from the ridges is in approximate balance with the up-glacial accumulation rate.

Rose (1979) suggested that Ice Stream B captured the drainage of Ice Stream C. That may be so, but it cannot explain the current result. At the simplest level, if there is ongoing capture, a positive balance for Ice Stream B and a negative balance for Ice Stream $C$ would be expected. The opposite has been observed: Ice Stream B and its drainage are thinning and Ice Stream C is virtually stagnant (McDonald and Whillans 1988, this volume).

\section{ACKNOWLEDGEMENTS}

The authors are grateful to Sion Shabtaie for providing the thickness profile in Figure 1, and to him, John Bolzan, Charles Bentley, and Mario Giovinetto for helpful criticism. The velocity determinations involved $M$. Gibbons, A. Templer, and Y.-H. Tseng, and M. Jackson computed the velocity profile and the discharge. T. Gentry and D. White worked on accumulation rates. M. Mabin calculated catchment areas. The manuscript was typed by Jodi Fortner and Mary Hill, and the illustrations are by Y. Holsinger, K. Tyler, and R. Tope. The work was supported by U.S. National Science Foundation grant DPP-8517590. This is Byrd Polar Research Center contribution No. 635 . 


\section{REFERENCES}

Bindschadler, R.A., D.R. MacAyeal, and S.N. Stephenson. 1987. Ice stream-ice shelf interaction in West Antarctica. In Veen, C.J. van der, and J. Oerlemans, eds. Dynamics of the West Antarctic Ice Sheet. Proceedings of a Workshop held in Utrecht, May 6-8, 1985. Dordrecht, etc., D. Reidel Publishing Company, 161-180.

Brecher, H.H. 1986. Surface velocity determination on large polar glaciers by aerial photogrammetry. Ann. Glaciol., 8, 22-26.

Bull, C. 1971. Snow accumulation in Antarctica. In Quam, L.O., ed. Research in the Antarctic. Washington, DC, American Association for the Advancement of Science, 367-421.

Clausen, H.B., W. Dansgaard, J.O. Nielsen, and J.W. Clough. 1979. Surface accumulation on Ross Ice Shelf. Antarct. J. U.S., 14(5), 68-72,

Delmas, R., and M. Pourchet. 1978. Utilization des filtres échangeurs d'ions pour l'étude de l'activité $\beta$ globale d'un carottage glaciologique. IASH Publ. 118 (General Assembly of Grenoble 1975 - Isotopes and Impurities in Snow and Ice), 159-163.

Giovinetto, M.B. 1964. The drainage systems of Antarctica: accumulation. In Mellor, M., ed. Antarctic snow and ice studies. Washington, DC, American Geophysical Union, 127-155. (Antarct. Res. Ser., 2.)

Giovinetto, M.B., and C.R. Bentley. 1985. Surface balance in ice drainage systems of Antarctica. Antarct. J. U.S., 20(4), 6-13.

Gow, A.J. 1968. Deep core studies of the accumulation and densification of snow at Byrd Station and Little America V, Antarctica. CRREL Res. Rep., 197.

Gow, A.J., and R. Rowland. 1965. On the relationship of snow accumulation to surface topography at "Byrd Station", Antarctica. J. Glaciol., 5(42), 843-847.

Gow, A.J., and T. Williamson. 1976. Rheological implications of the internal structure and crystal fabrics of the West Antarctic ice sheet as revealed by deep core drilling at Byrd Station. Geol. Soc. Am. Bull., 87(12), 1665-1677.

Gow, A.J., H.T. Ueda, and D.E. Garfield. 1968. Antarctic ice sheet: preliminary results of first core hole to bedrock. Science, 161(3845), 1011-1013.

Hooke, R.LeB. 1981. Flow law for polycrystalline ice in glaciers: comparison of theoretical predictions, laboratory data, and field measurements. Rev. Geophys. Space Phys., 19(4), 664-672.

Hughes, T.J. 1973. Is the West Antarctic ice sheet disintegrating? J. Geophys. Res., 78(33): 7884-7910.

Jezek, K.C. 1984. Recent changes in the dynamic condition of the Ross Ice Shelf, Antarctica. J. Geophys. Res., 89(B1), 409-416.

Lingle, C.S., and T.J. Brown. 1987. A subglacial aquifer bed model and water pressure dependent basal sliding relationship for a West Antarctic ice stream. In Veen, C.J. van der, and J. Oerlemans, eds. Dynamics of the West Antarctic Ice Sheet. Proceedings of a Workshop held in Utrecht, May 6-8, 1985. Dordrecht, etc., D. Reidel Publishing Company, 249-285.

McDonald, J., and I.M. Whillans. 1988. Comparison of results from Transit satellite tracking. Ann. Glaciol., 11, 83-88.

Parish, T.R., and D.H. Bromwich. 1986. The inversion wind pattern over West Antarctica. Mon. Weather Rev., 114(5), 849-860.

Parish, T.R., and D.H. Bromwich. 1987. The surface windfield over the Antarctic ice sheets. Nature, 328(6125), $51-54$.

Paterson, W.S.B. 1983. Deformation within polar ice sheets: an analysis of the Byrd Station and Camp Century borehole-tilting measurements. Cold Reg. Sci. Tech., 8(2), 165-179.

Pourchet, M., and F. Pinglot. 1979. Determination of the stratospheric residence time from the total $B$ activity of Antarctic and Greenland snows. Geophys. Res. Lett., 6(5), 365-367.

Pourchet, M., F. Pinglot, and C. Lorius. 1983. Some meteorological applications of radioactive fallout measurements in Antarctic snows. J. Geophys. Res., 88(C10), 6013-6020.

Rose, K.E. 1979. Characteristics of ice flow in Marie Byrd Land, Antarctica. J. Glaciol., 24(90), 63-75.

Schwerdtfeger, W. 1984. Weather and climate of the Antarctic. Amsterdam, etc., Elsevier.

Shabtaie, S., and C.R. Bentley. 1987. West Antarctic ice streams draining into the Ross Ice Shelf: configuration and mass balance. J. Geophys. Res., 92(B2), 1311-1336.

Shabtaie, S., I.M. Whillans, and C.R. Bentley. 1987. The morphology of ice streams A, B and C, West Antarctica, and their environs. J. Geophys. Res., 92(B9), 8865-8883.

Shabtaie, S., C.R. Bentley, R.A. Bindschadler, and D.R. MacAyeal. 1988. Mass-balance studies of ice streams A, B, and C, West Antarctica, and possible surging behavior of Ice Stream B. Ann. Glaciol., 11, 137-149.

Turcotte, D.L., and G. Schubert. 1982. Geodynamics, applications of continuum physics to geological problems. New York, Wiley.

Vickers, W.W. 1966. A study of ice accumulation and tropospheric circulation in western Antarctica. In Rubin, M.J., ed. Studies in Antarctic meteorology. Washington, DC, American Geophysical Union, 135-176. (Antarct. Res. Ser., 9.)

Vornberger, P.L., and I.M. Whillans. 1986. Surface features of Ice Stream B, Marie Byrd Land, West Antarctica. Ann. Glaciol., 8, 168-170.

Whillans, I.M. 1975. Effect of inversion winds on topographic detail and mass balance on inland ice sheets. J. Glaciol., 14(70), 85-90.

Whillans, I.M. 1977. The equation of continuity and its application to the ice sheet near "Byrd" Station, Antarctica. J. Glaciol., 18(80), 359-371.

Whillans, I.M. 1978. Surface mass-balance variability near "Byrd" Station, Antarctica, and its importance to ice core stratigraphy. J. Glaciol., 20(83), 301-310.

Whillans, I.M. 1979. Ice flow along the Byrd Station strain network, Antarctica. J. Glaciol., 24(90), 15-28.

Whillans, I.M. 1981. Reaction of the accumulation zone portions of glaciers to climatic change. J. Geophys. Res., 86(C5), 4274-4282.

Whillans, I.M. 1987. Force budget of ice sheets. In Veen, C.J. van der, and J. Oerlemans, eds. Dynamics of the West Antarctic Ice Sheet. Proceedings of a Workshop held in Utrecht, May 6-8, 1985. Dordrecht, etc., D. Reidel Publishing Company, 17-36.

Whillans, I.M., and J. Bolzan. In press. A method for computing shallow ice-core depths. J. Glaciol., 34(118).

Whillans, I.M., J. Bolzan, and S. Shabtaie. 1987. Velocity of ice streams B and C, Antarctica. J. Geophys. Res., 92(B9), 8895-8902.

White, D.J. Unpublished. A determination of ice accumulation rates on the West Antarctic ice sheet, Marie Byrd Land, Antarctica. (B.Sc. thesis, The Ohio State University, 1987.) 